\title{
QFD EXAMPLE IN INTERACTION WITH HMI
}

\author{
IngA ChudjaKova*，JAROMÍR TOBIŠKA \\ ŠKODA AUTO a.s., Tř. Václava Klementa 869, Mladá Boleslav, 293 60, Czech Republic \\ * corresponding author: Inga.Kadlecova@skoda-auto.cz
}

\begin{abstract}
This article focuses on the application of the Quality Function Deployment (QFD) method and shows how we can use this method in the automotive industry. The cockpit of the modern car is still developing and changing according to technical progress and customers' requirements. The QFD method enables the setting of the customers' requirements and then puts them into technical expression. The matrix of QFD sets those technical expressions that are the most important properties customers expect. These chosen properties can be tested during the technical development. The testing of new HMI concepts goes through a driving simulator and can suggest which one is suitable for being used in a real car.
\end{abstract}

KEYwORDS: the QFD method, customers' requirements, automotive industry, DoE, HMI, driving simulator, House of Quality.

\section{INTRODUCTION}

Nowadays in the automotive industry, the aim of all car producers is customer satisfaction, but also technical progress, that can differentiate them in the current competitive environment. A set of quality methods serves/is used to achieve customer satisfaction in the automotive industry. They lead to production of high-quality production and are also related to higher profit.

\section{Quality Assurance Methods}

For the reasons above it is necessary to use the quality assurance methods in the automotive industry and use them at the beginning of the product development process. The QFD method, i.e. Quality Function Deployment, is one of these methods. This method is used mostly at the first stage of the product development process because the QFD method allows transformation of customer requirements into technical expression [1]. Its main task is the determination of customer requirements and their implementation in the process of the product preparation. Thanks to QFD methods, the designers can understand what customers want and it designs the product.

The methods used for optimizing the costs and the methods to prevent errors and faults in the development of a product also belong among the assurance methods. For more detailed classification of the quality assurance methods overview see the Fig. 1 .

By using QFD method(s) we can assess the fulfilment of the customers' requirement for products and processes. At the start of the QFD method application, there are the customer's requirements (wishes). To find out what the customers want we need to focus on the following:

a) Technical parameters, a physical element, a specified part of system

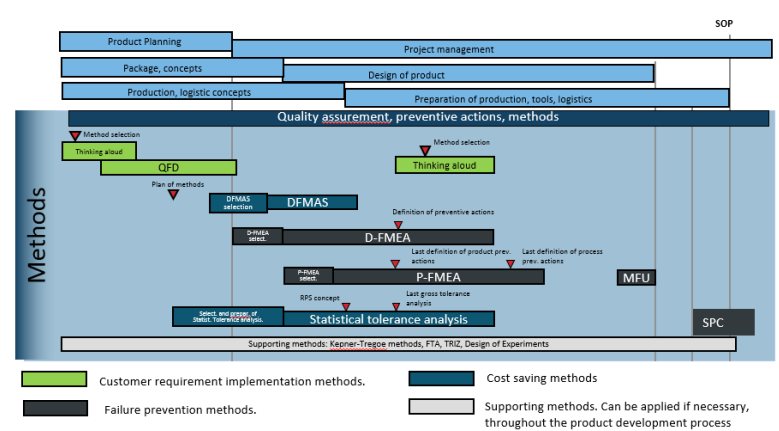

FIGURE 1. The quality assurance methods overview.

b)Defined procecesses, assembly operations, handling operations, specific actions

\section{QFD}
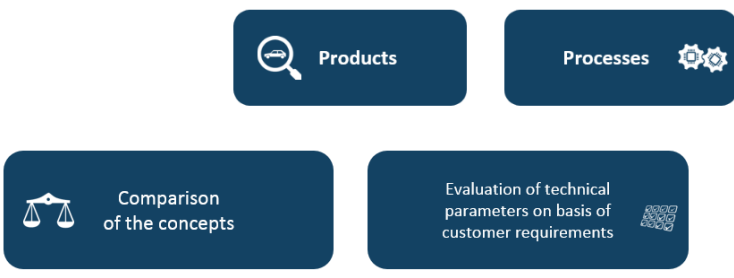

Figure 2. The QFD application.

The use of the QFD method is equal in the both cases. The difference is in the outcomes. We are able to find the key element of the system and the specific technical parameter, which we monitor to ensure the fulfilment of customers' requirements or key activities; the process which implementation may impact the consequences effecting the customers' satisfaction. 


\section{The Application of the QFD METHOD}

The basic outcomes of the QFD (Quality Function Deployment) method application are the answers to the two following questions:

- What are the customer's expectations?

- How can we meet these expectations? 1]

The QFD method is characterized by four application stages, which are as follows: Product proposal (a proposal of characteristic product properties), proposal of components, processes planning and production planning. Each of these stages is noted in a diagram and matrixes.

\subsection{Matrixes of the QFD Method}

The QFD method is based on the QFD matrix, which is often marked as the "House of Quality" and consists of a team of experts. The overall structure of the QFD matrix has 8 specified fields, but during the use the QFD matrix not all fields need to be completed. It is possible to use only a part of the QFD matrix, as required by the project. The QFD matrix that describes the most important field, can be seen at the graph bellow (see Fig. 3).

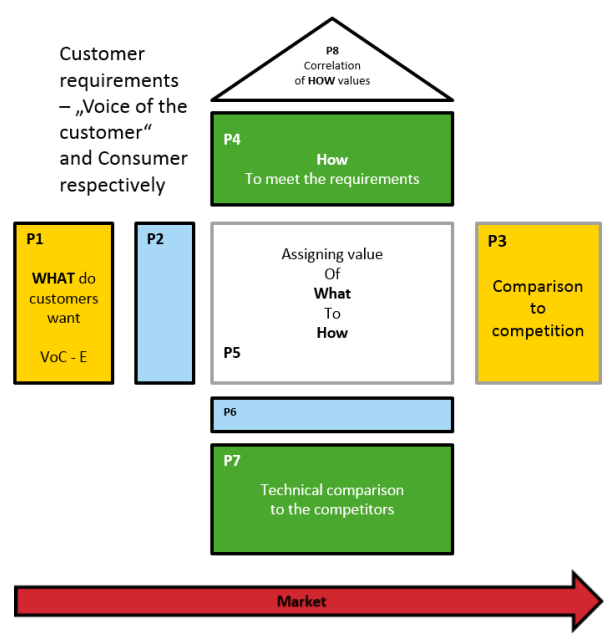

FIGURE 3. QFD matrix "The house of Quality".

For the completing of the QFD matrix it is not required to use a special programme or software, one can just fill an Excel table.

The most important thing for the using the QFD method and filling in the QFD matrix is to know the succession of inputs and outputs - for detail see Fig. 4.

The QFD method can interpret the customers' requirements, which are often defined only verbally, into the technical values that the designers can work with. To use the QFD method correctly, it is essential to get the inputs. This information can be obtained from:

- Surveys/Questionnaires

- Thinking loud (Lautes Denken)

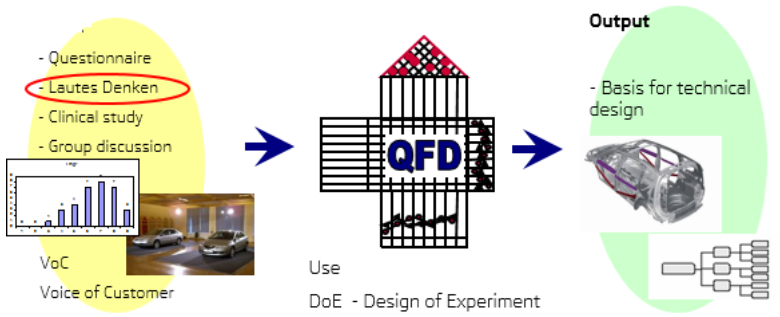

FIGURE 4. QFD method relations.

- Clinical studies

- Group discussions/Think tanks ???

- J. D. Power

These procedures are established in quantitative and qualitative research techniques. In order to receive the information needed, it is necessary to choose the right method, group of respondents, questionnaire, and also the form of responses for each project. The application of the entire QFD method is based on obtaining these input data.

Then the matrix is completed with technical solutions that could have an influence on the customers' requirements. The technical parameters may be defined by using accurate parameters or units. Therefore, the best technical solutions are those that influence several customer wishes at once.

The correlation between the customers' expectations and the technical parameters is placed in the main field of the QFD matrix. This mutual correlation shows how much the technical solution will influence the customers' expectations. The mutual influence may have the following values: $0=$ no influence, 1 = low influence, $3=$ average influence, or $9=$ huge influence.

\section{A Practical Example of Application of THE QFD Method in the Automotive INDUSTRY}

At the present time, the load of the driver while driving is increasing. This is caused by the improvement of technology and development of the HMI systems in cars. Also, the proportion of displaying and controlling components in the cockpit is increasing.

An interaction between these car systems, displaying components and a driver may affect driving safety in a remarkable way 2]. For the practical example of using QFD method, we need to optimize the display to ensure safe operation while driving. For setting of the car display properties of we used QFD method.

In order to use the QFD method, firstly we needed to find out which display properties customers found the most important. These were the inputs into the QFD matrix and we had used the qualitative and quantitative techniques and methods. The input data were received due to an evaluation of the questionnaires, 
where respondents assessed the general properties of a display independent of the tested concepts. For these customers' expectations, the technical experts set the technical parameters, which is are in the field $\mathrm{P} 4$. Then the teams set the correlations between the customers' expectations and technical parameters at the field P5. After the calculations of QFD matrix, in the field $\mathrm{P} 6$ we can see which technical parameters had effected the customers' expectations the most.

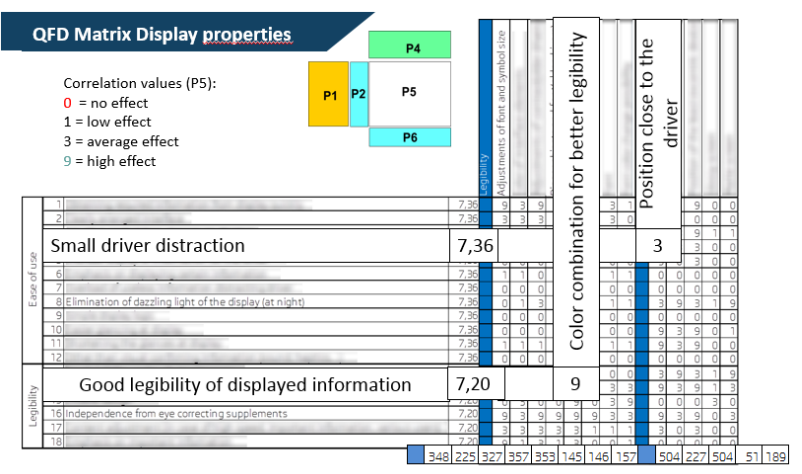

FiguRE 5. Example of QFD matrix.

The highest rated technical expressions from the QFD matrix were tested in the technical clinic through a driving simulator. In these clinics, the highest rated expressions were: a font size, font legibility, text understanding and contrast. These parameters were tested separately on a separate screen.

Several chosen screens from the display menu were tested. They display various combinations of the script sizes and contrast. The respondents were expected to assess the individual items on each screen, such as a script legibility, text comprehension and contrast. The above-mentioned testing revealed that the best combination of good display legibility for customers is the second biggest letter size of the tested script with combination of the best contrast (contrast 1), because the biggest font size can be distracting $[3]$.

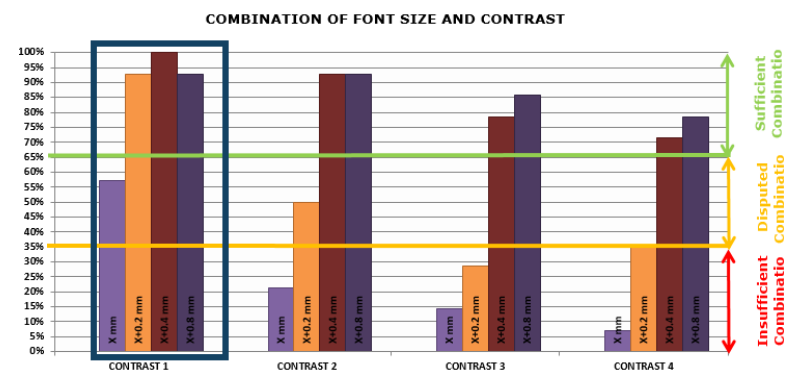

Figure 6. Combination of fontsize and contrast.

\section{Conclusion}

The QFD method is an integral part of a product development in the automobile industry. Its contribution is provable in all the stages of the car development process as well as in the area of the HMI concept testing. The main objective of the HMI systems testing is the minimization of the time that these systems are controlled and thus the time that the driver is not concentrating on driving. Together, these methods contribute to customers' satisfaction, which has been nowadays emphasized more and more in the automotive industry.

\section{REFERENCES}

[1] J. Machan, J. Tobiška, et al. Metody kvality užívané ve fázi vývoje výrobku - aplikace $v$ automobilovém průmyslu. II.a revised and expanded edition, Prague 2012, 117 p., ISBN 978-80-87042-50-2.

[2] M. Novák, P. Bouchner, J. Faber, et al. Senioři za volantem. Prague: Faculty of Transportation Sciences, Czech Technical University in Prague, 2008, ISBN 978-80-87136-20-7.

[3] Zvláštni projekty elektrostrategie a výzkumu, Technický vývoj, Škoda Auto a.s.: Projekt HMI ve ŠKODA AUTO. (prezentace), Mladá Boleslav, an internal document, 2013. 